\title{
Генномолекулярна интерперетация на биологичните процеси на слуховъзприятието
}

\author{
Е. Ценев, Ив. Ценев, М. Милков \\ PAN Klinik - Köln - Deutschland \\ УМБАЛ „Ц. Йоанна“ - София \\ Медицински университет - Варна
}

\begin{abstract}
Резюме
Човешкият слухов орган е един от най-сложно устроените предназнаен за възприемане на акустичните механични сигнали от външната среда.Вътрешното ухо е високо специализираният орган за сензитивни възприятия в което се комбинират три свързани помежду си функции изпълнявани от organon Corti ,stria vascularis и gangion spiralis. Адекватното дразнене на слуховия орган са механичните трептения възбудени от различни звукови източници транспортирани и разпространявани от въздуха навлизат през овалното прозорче към пери и ендолимфата до слуховите клетки в кортиевия орган. В него се намират два типа клетки - вътрешни слухови клетки детерминирани за трансформиранене на механичните звукови сигнали в биоелектрични потенциали и външни които са генетично предопределени за усилване селективитета и сензитивитета на постьпилите акустични сигнали.
\end{abstract}

\section{Молекулярна интерпретация на слуха}

\section{Съдържание}

Човешкото ухо с анатомичното си устройство е напълно адаптирано за трансформиране на механичната кинетична звукова енергия и превръщането и във високо специализирана биоелектрична. Вътрешното ухо е един от най-чувствителните органи на човека съставен главно от три последователно функционално свързани сектора: organon Corti,stria vascularis, ganglion spiralae. Адекватният дразнител за тази комплицирана сензитивна система са акустичните сигнали, които се транспортират през външното, средното и оттам към вътрешното ухо респ. вътрешните слухови клетки. В последните години беше детерминирано изключително важната за тези клетки функция, а именно, превръщането на механичната енергия в биоелектрични импулси. Така например stria vascularis е отговорна за поддържането на кохлеарната хомеостаза, а спиралният ганглии изгражда и формира синаптичните контакти със слуховите клетки по които се пренасят по аферентните аксони нервните сигнали до мозъчната кора. Днес все повече внимание се отделя върху влиянието на различните генетични аномалии, които са отговорни за синтезата на огромните разновидности протеини, особено контрактилните типове и тези обслужващи йонните канали.

\section{Физиология на слуховия орган}

Периферният слухов орган се разделя на три отдела: 1. Външно ухо с ушна мида и слухов канал 
2. Средно ухо с тимпанална мембрана, кухина на средното ухо, слухови костици и мускули и

3. Вътрешно ухо разположено дълбоко в темпоралната кост с преддверие и кохлея с organon cochleae и полуокръжни канали с прилежащите вътрешен слухов проход и аксони до кората на мозъка.

1. Външно ухо. Външното ухо се акцептира, като акустична антена, която диференцирано насочва звуковите сигнали към тъпанчевата мембрана. Аурикулата и канала представляват приблизително фуния, която за определени фреквенции от наличния резонанс повишават силата на попадналите звукови сигнали. Това са фреквенциите в диапазона между $2-4 \mathrm{kHz}$ т.е. говорните зони, с което се обяснява факта, че субекти експонирани на шум в този диапазон имат често увреден слух. Лявото и дясното външно ухо обуславят пространствено разпределение на звуковите вълни върху тимпаналните мембрани, предопределящо пространствената ориентация. Освен това всяка, аурикула създава условия за диференцирано изменение в двете посоки на звуковата вълна: една попадаща директно през cavum conchae и втора рефлектирана от helix и anthelix. Втората вълна има малко по-дълъг път осъществяваща звуково закъснение около 0,2 ms. което се отразява на звуковата локализация върху вертикалната плоскост на мембраната

2. Средно ухо. Средното ухо се разполага в една пневматизирана кухина на слепоочната кост, която се аерира през Евстахиева трьба от епифаринкса. Осикуларната верига разположена между тимпаналната мембрана и овалното прозорче пренася осцилациите, към перилимфата на вътрешното ухо. Най-важната функция на средното ухо е изравняване на импеданса (съпротивлението) между различните съпротивления (импеданси) тази на въздуха и на течностите (във вътрешното ухо), което е възможно чрез механизъма на средното ухо. Преодоляване съпротивлението на течностите и ефективното пренасяне на звуковата вълна се реализира само ако този механизъм работи нормално. Ако системата на средното ухо липсва, то $\geq 99 \%$ от звуковата енергия би се загубила и само около $\leq 1 \%$ ще остане ефективна (фиг. 1) за слуховъзприятието. Задачата на средното ухо е именно да намали максимално загубата на звуковата енергия да я минимизира и да я трансмисира с минимална загуба към перилимфата. За целта помага голямата разлика в площите между тимпаналната мембрана и основната плочка на стремето, които са в съотношение 20:1 което е най-важният фактор. Като механично вибрираща система средното ухо показва и резонансна фреквенция, която усилва пренасяната енергия от около $1 \mathrm{kHz}$. Върху импеданса влияние оказват и атмосферните промени, функция която се изпълнява от tuba Eustachii през която се изравнява налягането от периодично постьпване на атмосферен въздух. Функцията на статично изравняване налягането между двете кухини - епифаринкс и средно ухо се допълнително подсигурява от ставните връзки на слуховите костици, които не позволяват дислоциране на основната плочка на стремето при екстремални акустични натоварвания.

3. Вътрешно ухо. Представлява система от взаимно свързани костни канали в които се разполагат ципестите му структури разположени в масива на слепоочната кост. В ципестите канали се намират два типа сензитивни компоненти: слухов охлюв и вестибуларни полуокръжни канали.

3.1. Охлюв (Cochlea). Кохлеята е от основно физиологично и клинично значение за възприемане на различните акустични емисии върху човека. Охлювът се изгражда от костен канал canalis spiralis cochleae и дължина приблизително 31-35 mm със завит спирален ход около една oc, modiolus от която периферно се излъчва костна ламела - lamina spiralis cochlea. По този начин се формират три независими костни прос-

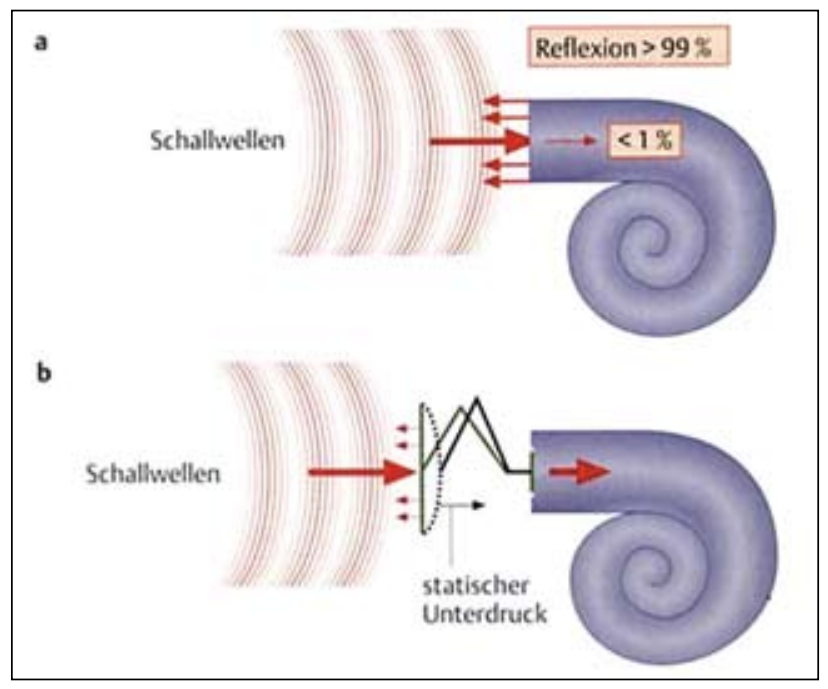

Фиг. 1. При липса на средно ухо се губи около $99 \%$ от ефректа на звуковъзприятието 
транства: scala media, scala vestibuli et scala tympani. От lamia spiralis към периферията на охлюва се излъчва membrana basilaris, която в долната част има дължина 0,1 мм, а във високата към върха 0,5 мм и значително по-тънка в сравнение с основата. Тя стои опъната между lamina spiralis ossea и ligamentum spirale - който представлява едно съединително тъкано уплътнение на външната страна на охлюва. Върху базиларната мембрана се разполага organon spiralae Corti съставен от ресничести сензитивни (слухови) и опорни клетки, покрити от текториалната мембрана, която се залавя за lamina spiralis ossea.

\section{2. Орган на Cort}

Въведение. Кортиевият орган изпълнява ролята на начален сензоневрален трансдукционен механизъм на слуха. Тази структура е наречена на името на италианския анатом Alfonso Giacomo Gaspar Corti (1822-1876). В този орган са намерили подслон два типа - външни и вътрешни ресничести сензитивни клетки (рецептори), които са подкрепяни от опорни клетки. Във всеки Кортиев орган се намират около 15000 клетки разположени по хода на ductus cochlearis. Около ductus cochlearis се разполагат рецепторните клетки съставен от: вътрешни клетки (към модиолуса) съставени само от една клетка, докато външните подредени срещу вътрешните са подредени по три в редица (фиг. 2). Доказано e, че вътрешните, реснически слухови клетки са истинските сензитивни акустични рецептори (1) които имат възможност да изпращат биоелектрични импулси към спиралния ганглии респ. слуховия нерв, докато външните ресничести клетки имат функцията да повишават кохлеар-

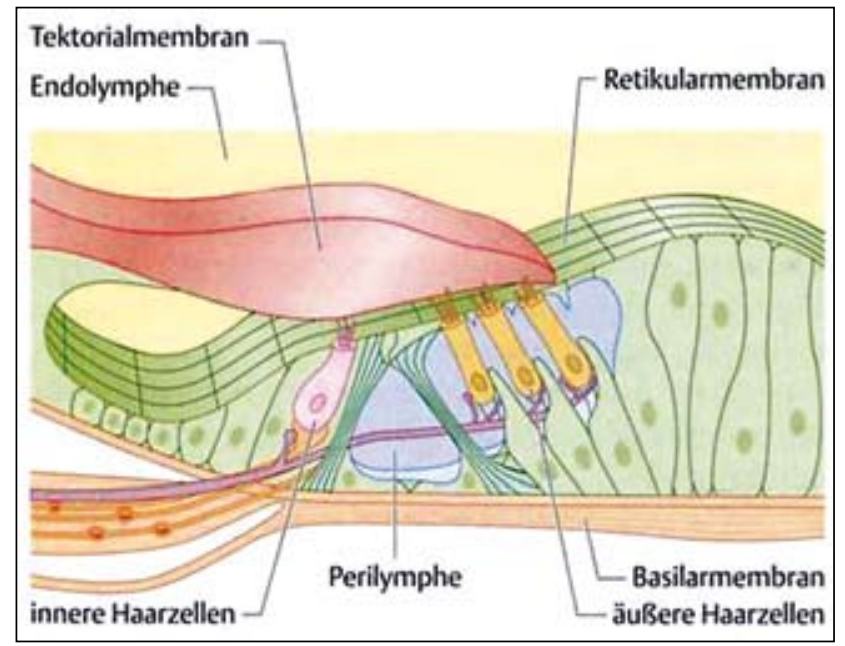

Фиг. 2. Структура на organon Corti - една вътрешна и три външни клетки

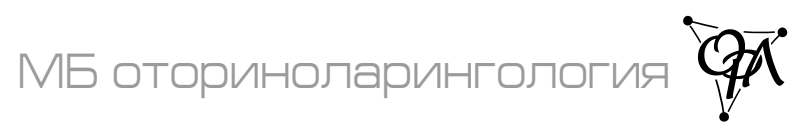

ните - качествени (увеличаване на селективитета) и количествените (повишаване на сензитивитета) възможности на вътрешното ухо. Върху горната повърхност на всяка слухова клетка се намира снопче от реснички, които се приемат като механосензитивните органели на клетките. В това снопче се намира един неподвижен kinocilium и множество силно флексибилни и мобилни stereocilium. Отделните стероцилиуми към върховите части са свързани помежду си с еластични връзки т. нар. „Tip-Links“. Слуховите и опорните клетки са подредени като мозайка, като всяка сензитивна слухова клетка се подкрепя от четири опорни. Всички слухови клетки в органа на Corti са високо диференцирани и под тях няма базални недиференцирани клетки, както е в другите епителни тъкани, което е причина за липса на регенераторен капацитет на акустичния сензитивен епител.

3.3. Тонотопия. Когато звуковата вълна постъпи през външния слухов проход и раздвижи тимпаналната мембрана, трептенето се предава на веригата слухови костици вкл. и плочката на стремето която раздвижва перилимфата на scala vestibuli. При движението на перилимфата към върха-хеликотрема настьпва последващо огъване на membrana basilaris. Ако този механизъм на средното ухо липсваше то $99 \%$ от звуковата енергия би се отразила и загубила в околното пространство (фиг. от Пробс). Според теорията на v. Bekesy от 1928 г. раздвижването на стремето индуцира обемно раздвижване на перилимфата в ductus cochlearis. Така възникналата вълна се насочва от стремето към helicotrema, като се оформя в някои от зоните на базиларната мембрана максимален размах на огъване на мембраната и образуване на т. нар. стояща вълна (фиг. 3). Този пункт зависи от честотата на изходния звуков сигнал. Това е основният принцип за тонотопичната организация на кохлеята. Огъването на базиларната мембрана води до раздвижване на membrana tectoria която раздвижва вилозните структури при което се създават условия за появата на т. нар. режещи в тангенциална посока сили. Тези сили върху слухови клетки се приемат като адекватно дразнене за механорецепторните вътрешни слухови клетки.

3.4. Механатрансдукция. За вътрешните слухови клетки е доказано, че са предназначени за превръщане на механичната енергия 
- породена от огъната базиларна мембрана - в електрични импулси и невронална активация на ганглийните клетки разположени в gangl. spiralae. В основата на този процес се намира т. нар. механоелектрична трансдукция $(3,4,5)$. Най-важните компоненти на акустичната трансформация е наличието в ресничестите клетки на йонните канали, които се определят от връзката Tip-Link. Това е една нишковидна протеина структура която свързва стереоцилиите една с друга към върховите им сегменти $(6,7)$. Механичното раздвижване на един комплексно свързано снопче от стереоцили създават условия за появата на режещи сили между отделните стереоцилии. Снопчетата от стереоцилии реагират изключително бързо на огъванията предизвикани от звуковата вълна на базиларната мембрана. Така напр. при нормален слухов диапазон на вълната огъването е по-малко от $1 \mathrm{~nm}$, а ьгъльт на отклонението достига максимално $-1^{\circ}$. Слуховите клетки реагират при огъването с отваряне и затваряне на йонните канали. При липса на акустични стимули йонните канали периодично се отварят и затварят с приблизителна вероятност на отворено състояние (Ро) по-малко от -0,1. (8). Изкривяването на снопчето стереоцили в направление към найвисокия стероцилии (позитивно наклоняване) повишава времето на отвореното състояние на йонните канали, докато обратно наклоняване към късите стероцилии (негативно наклонение) затваря йонния канал.

\section{5. Ресничестите снопчета и трансдукци-} оннен anapam. Въпреки механоелектричната трансдукция на ресничестите клетки, (която се проучва интензивно) до настоящия момент все още се знае твърде малко, като остава неясен проблемът кои протеини са отговорни за биофизикалните процеси на механотрансдукцята. Наскоро за обяснение на тези процеси се идентифицираха някои от множеството протеини, като основните са Cadherin, Myosin и някои протеини участващи в изграждането на различни решетъчни структури, а именно Protocadherin (PCDH 15), Cadherin 23 (CDH 23), които моделират връзката Tip-Link между киноцилиума и най-високите и близко разположени до него стероцилиуми $(9,10,11)$. G-протеина се асоцирира с рециптор 1 (VLGR 1), a Usherin топикално се намира разположени в основата на стериоци- лиума, където те изграждат т. нар. Ankle-Links. Този връзка от протеин се намира главно във вестибуларните ресничести клетки, докато в акустичния епител той преобладава предимно в ранните фази по време на развитие му. Myosin VI (MYO 6) се среща в голямо количество в кутикуларната плака и апикалната зона на ресничестите сензитивни клетки.Myosin VII A ce доказва в стероцилиите и отчасти в по-голямо количество се намира и в Ankle-Links (fig. 3). Досега познатите данни за Cadherin 23, Protocadherin 15 и Myosin 1с се интерперитрат (12, $13,14)$ като вероятните кандидати за централни елементи за извършване на механотрансдукцията в слуховите клетки. (фиг. 3).
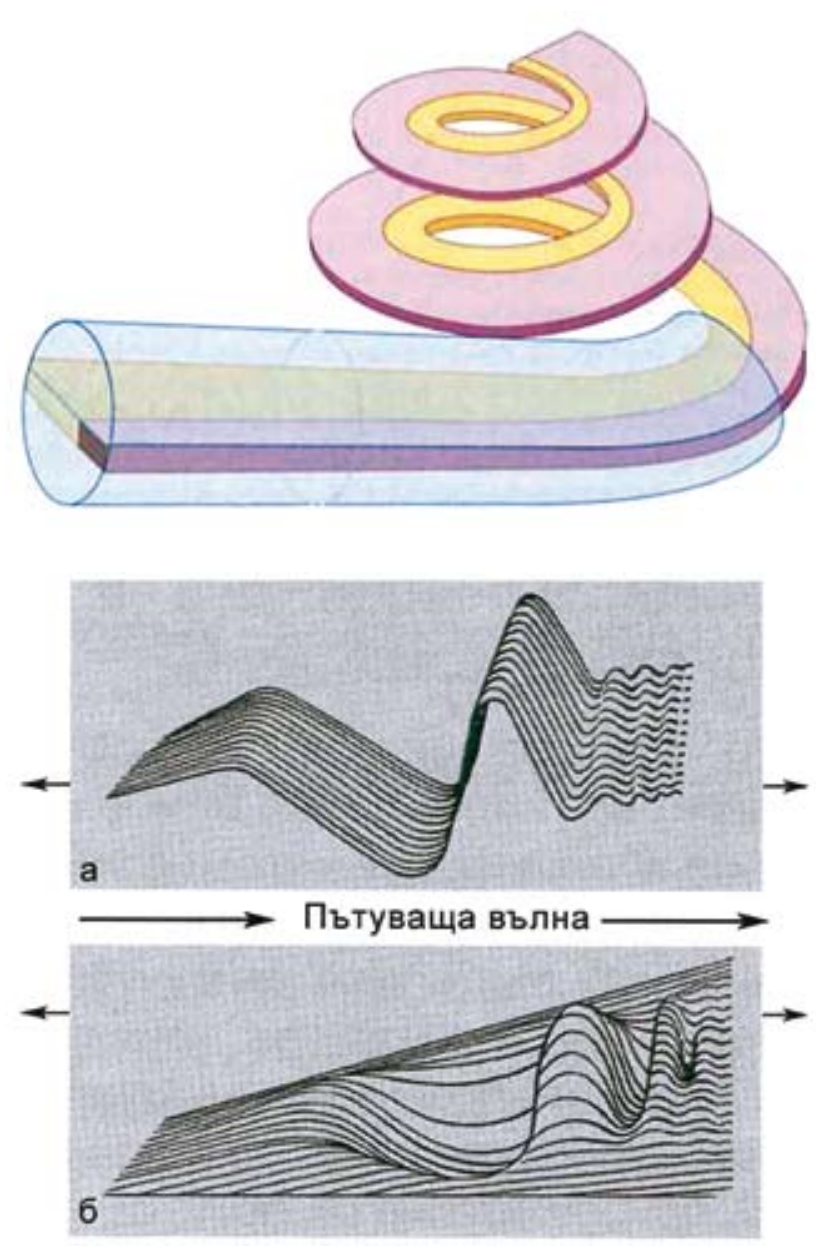

Фиг. 3. Схема на membrana basilaris и пътуваща вълна

Usher syndrom. Синдромът на Usher се дължи на мутация на гена кодирани за синтезата на Myosin VIIa, Cadherin23 u Procadherin 15, кoumo дават различни по тежест типове от синдром Usher (14, 15). Мутацията на човешкия тип МYО7А се приема като гентична причина за синдрома на Usher.Някои синдроми напр. Tур 1 
B $(15,16)$ или Тур 2A(17). Синдромът на Usher се номинира като причина за най-честата аутозомна рецесивна форма на синдромалната глухота при който освен слуховите има и зрителни дефекти. Глухотата е най-често високо степенна приемна или в умерена форма настьпила непосредствено след раждането. Зрителният дефект се детерминира след първите 10 години от живота на индивида и бързо прогресира, понякога до пьлна глухота с придружаваша retinopathia pigmentosa, кокоша слепота, катаракта, стесняване на зрителното поле, а в по-късен етап и пълна слепота. Възможно е и появата на статокинетични смущения които не са задължителни.

3.6. Адаптация. Една особеност на ресничестите клетки е тяхната възможност за адаптация. Този своеобразен механизъм представлява способността на ресничестите клетки за неограничена сензитивна реакция, независимо от наклоненото състояние на стереоцилиите над определените нормални по време и отклонение в $\mathrm{nm}$ състояние Молекулярният механизъм на адаптацията е почти добре разгадан. След наклоняването на стероцилиите в началото Tip-Link, най-напред се опъва, което води до отваряне на трансдукционния канал, като през това време от ендолимфата нахлуват $\mathrm{K}^{+}-\mathrm{Ca}^{2+}$ йони през отворения механоелектричен трансдукционен канал в ресничестата клетки, водещо до деполяризация на клетката. Едновременно с нахлулия $\mathrm{Ca}^{2+}$ започва активация на миозиновите молекули които се откъсват от актин филаментите. Този процес вероятно е свързан с $\mathrm{Ca}^{2+}$ свързания протеин Calmodulin (фиг. 4). Около $100 \mathrm{~ms}$ след отварянето на каналите се размества горното място на фиксация на Tip-Link, като се премества на по-ниско ниво, при което
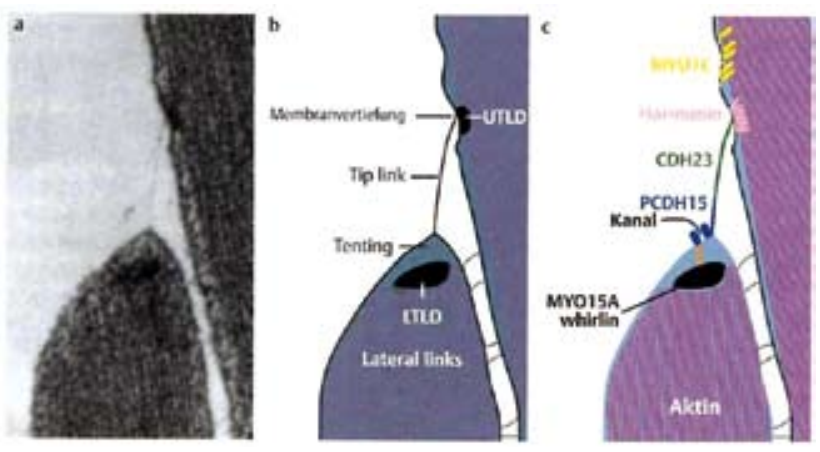

Фиг. 4. Организация на протеините молекули и Tip Link връзките. напрежението на Tip-Link значително намалява и трансдукционният канал се затваря, a $\mathrm{K}^{+}$спира да навлиза към клетката, тя отново се изправя и заема нормалната си позиция и възстановява максималния сензитивитет. Разместването на горния пункт на залавяне на Tip-Link се определя като адаптационен мотор. Когато стререоцилиите се върнат в тяхното първоначално изправено спокойно състояние, адаптационният мотор отново връща залавното място на изходната позиция на Tip-Link, което означава, че слуховата клетка е адаптирана.

Адаптационният механизъм се приема, че има два процеса: първият наречен „бърз“ и вторият „бавен“ $(1,8)$. Бързият адаптационен механизъм се наблюдава в слуховия и вестибуларния сензитивен епител. Този механизъм се основава на навлизане през трансдукционните канали на $\mathrm{Ca}^{2+}$-йони, свързан е с движението на ресничестите снопчета и е асоцииран с посоката на стимула. Бавната адаптация е свързана с адаптационният мотор, при които преместването на горния фиксационен пункт на Tip-Link надолу, като връзката се отпуска и слуховата клетка е отново готова за реагиране. Myosin1c, който е локализиран в края Tip-Link ce интерпретира като централен компонент на адаптационния мотор, въпреки участието и на други многобройни варианти миозини, но най-важната молекула на Tip -Link ca Myosin XVa(MYO15a) Whirlin.Te се намират в края на актин филаментите на стероцилиите. При мутации на генът които е кодиран за Whirlin, настьпва клиничната проява на Usher syndrom Type 2D.

3.7. Кохлеарно усилване. Кохлеарното усилване $(18,19,20)$ служи за динамично напасване, но също и за възприемане на ниски звукови нива, при което се наблюдава около 1000 пъти увели-
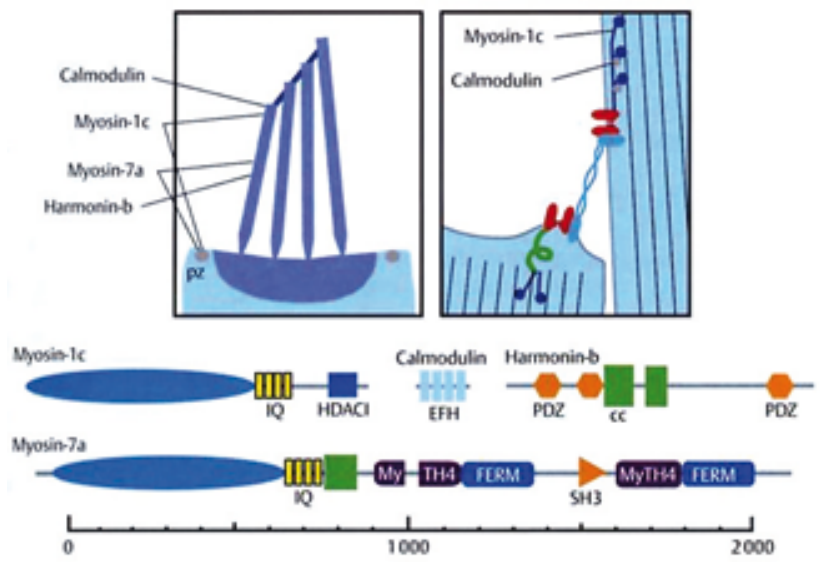
чаване на нелинеарно усилване на пътуващата вълна в punctum maximum върху membrana basilaris (приблизително до 50dB). Кохлеарното усилване е необходимо за възприемане на слабите звукови нива, като например шумове с ниски акустични интензитети. В основата на механизъма на кохлеарното усилване се намира Prestin-овата молекула и соматичния мотилитет на външните слухови клетки поради активното движение на снопчета от реснички. Външните слухови клетки имат възможността да променят формата и големината си и по този начин да използват механичните въздействия оказвани върху тях от огъванията на базиларната мембрана. Това е основният механизъм на соматичния мотилитет на външните слухови клетки. Огъването на базиларната мембрана нагоре се последва от притискане на стереоцилиите към текториалната мембрана и деполяризация им. Този ефект е последван от бърза контракция, което засилва движението на базиларната мембрана, като реакция от звуковото дразнене (21).

3.8. Соматичен мотилитет. Приема се, че за соматичния мотилитет при бързите моторни процеси е отговорен във външните слухови клетки Prestinà.Това може да се докаже при клетки, които трансфицират Prestin,товия електромотилитет който е около $0,2 \mu \mathrm{m}$. Експресията (продукцията) на престин може да се докаже имунохистохимично при което в зоната на латералната мембрана на външните слухови клетки, се намира и соматичния електромотилитет. Вътрешните слухови клетки, които не показват мотилитетни възможности, не показват данни за производството на престин.

Prestin. Значението на престина за функцията на външните слухови клетки се доказва в Prestin Knockout-Mause при които се наблюдава частична загуба на DPOAE съпроводено от тежка слухова загуба. При хора този вроден дефект на моторния протеин Prestin води до тежка сензитивна глухота $(22,23)$.

Престин (от италиански „Presto“-бърз) е гликопротеин съставен от 744 аминокиселини с молекулярно тегло $81,4 \mathrm{kDa}$. Той се приема като транспортьор на аниони във външните слухови клетки за обмяната на хлориди и карбонатите. Моторният протеин престин има възможност да променя своята големина, и да приема различни конфигурации. Престинът се намира нормално в т. нар. „късо състояние“ при условие, че клетъчната мембрана е деполяризирана, състояние при което хлоридните йони са свързани с цитоплазматична страна на клетката. Ако клетката е хиперполяризирана свързаните хлорни йони се траслоцират от външната страна на целуларната мембрана, а престина се намира в ,дълго състояние“. Тези изменения са съгласувани и с промяна във формата и големината на външните слухови клетки $(23,24)$.

3.9. Стереоцилиарен мотилитет. Стереоцилиарният мотилитет е един друг механизъм, който служи за увеличаване на кохлеарното усилване. Тук се касае за активното движение на снопчетата от стереоцилии които се повлияват от двата процеса на трансдукция и адаптация. Точната роля на соматичния и стререоцилиарния мотилитет все още се дискутира твьрде контроверзно. Смята се за доказано, че от този усилващ механизъм възникват отоакустичните емисии (OAЕ). Процесът на ОАЕ е клинично релевантен, тъй като чрез него може да се докаже функцията на външните слухови клетки и тяхната усилваща кохлеарна функция.

\subsection{1. Текториална мембрана. Текториална-} та мембрана е една ацелуларна съединително тъканна структура покриваща ресничестите клетки на Кортиевия орган от основата до апекса. Тя контактува в медиалния край с интерденталните клетки на limbus lamina spiralis. При електронно микроскопските изследвания е било установено две специфични идентифицирани структури-фибрилерен и нефибрилерен матрикс.

\subsection{2. Протеини на текториалната мембра-}

на. Значението на текториалната мембрана за слуха е доказано на опитни животни, при дефекти на която са показвали силно намален слух до пълна глухота като ефект на спонтанна мутация на alpha tektorins. При тези животни текториалната мембрана е показвала отлепяне от ресничките на слуховите клетки със загуба на неколагенния матрикс. Alpha tektorine са екстрацелурани матриксни протеини и като такива се намират в изобилно количество в състава на текториалната мембрана. При фамилии с мутации на човешките ортоложен ген TECTA (DEFA12 и DFNA8) са показвали силно намален слух. Генът otog кодиран за продукцията на Otogelin е един N-glykosylisite протеин на текториалната 
мембрана. Прицелни увреждания на този ген е давал силно намаление на слуха. Otoancorin e друг протеин, които се локализира в зоната на връзката между текториалната мембрана и limbus spiralae които е кодиран върху Gen OTOA, а мутацията му води до DFNB22 .Не на последно място е и значението на текториалната мембрана за тонотопичната организация на organon Corti.

\section{Stria vascularis}

1. Въведение. Stria vascularis представлява едно съединителна ивица тапицираща външната страна на ductus cochlearis organon Corti. Тя е съставена от множество преплетени кръвоносни капилярни съдове и още от три различни типове клетки: маргинални, интермедиерни и базални клетки. И трите типа клетки са от значение за функцията на спиралния лигамент (2). Изграждането на стрията се реализира от два типа епителни слоеве: единият слой се образува от маргиналните клетки, докато вторият се формира от интермедиерните и отчасти от базалните клетки. Екстрацелуларното пространство между двата слоя достига едва около $15 \mathrm{~nm}$ и се означава, като интрастриално. Това пространство е изпълнено с ацелуларен филтрат който електрически разделя пери от ендолимфата, а по химически състав е много близо до екстрацелуларната телесна течност. Няколко типа протеини комплекси създават тесни цепковидни пространства, които свързват различните клетъчни типове на спиралния лигамент, състояние което създава възможност за активна дифузия и обмен на органични и неорганични йонни, аминокиселини и др. $(25,26)$ (фиг. 5). Stria vascularis има централно значение за кохлеарната хомеостаза. Тя е отговорна за създаването и поддържането на ендокохлеарния потенциал и адекватното йонно съдържание на ендолимфата (фиг. 5). Дефекти на хомеосмозата води до нарушаване на ендокохлеарния потенциал, на йонния състав и обемно регулируемите механизми, последвани от загуба на слуха.

2. Йонна хомеостаза. Ендолимфата в scala meda показва в сравнение с останалите екстрацелуарни течности на тялото твърде висока екстрацелуларна концентрация на калиеви йонни - приблизително около $140 \mathrm{mmol} / \mathrm{l}$ и силно позитивен заряд, т. нар. ендокохлеарен потенциал с приблизителни стойности от $+85 \mathrm{mV}$, като ендокохлеарния потенциал, а също и високите калиеви концентрации се произвеждат в stria vascularis. $\mathrm{K}^{+}$градиент който заедно с ендокохлеарния потенциал са в основата на механоелектричната трансдукция на ресничестите клетки. На

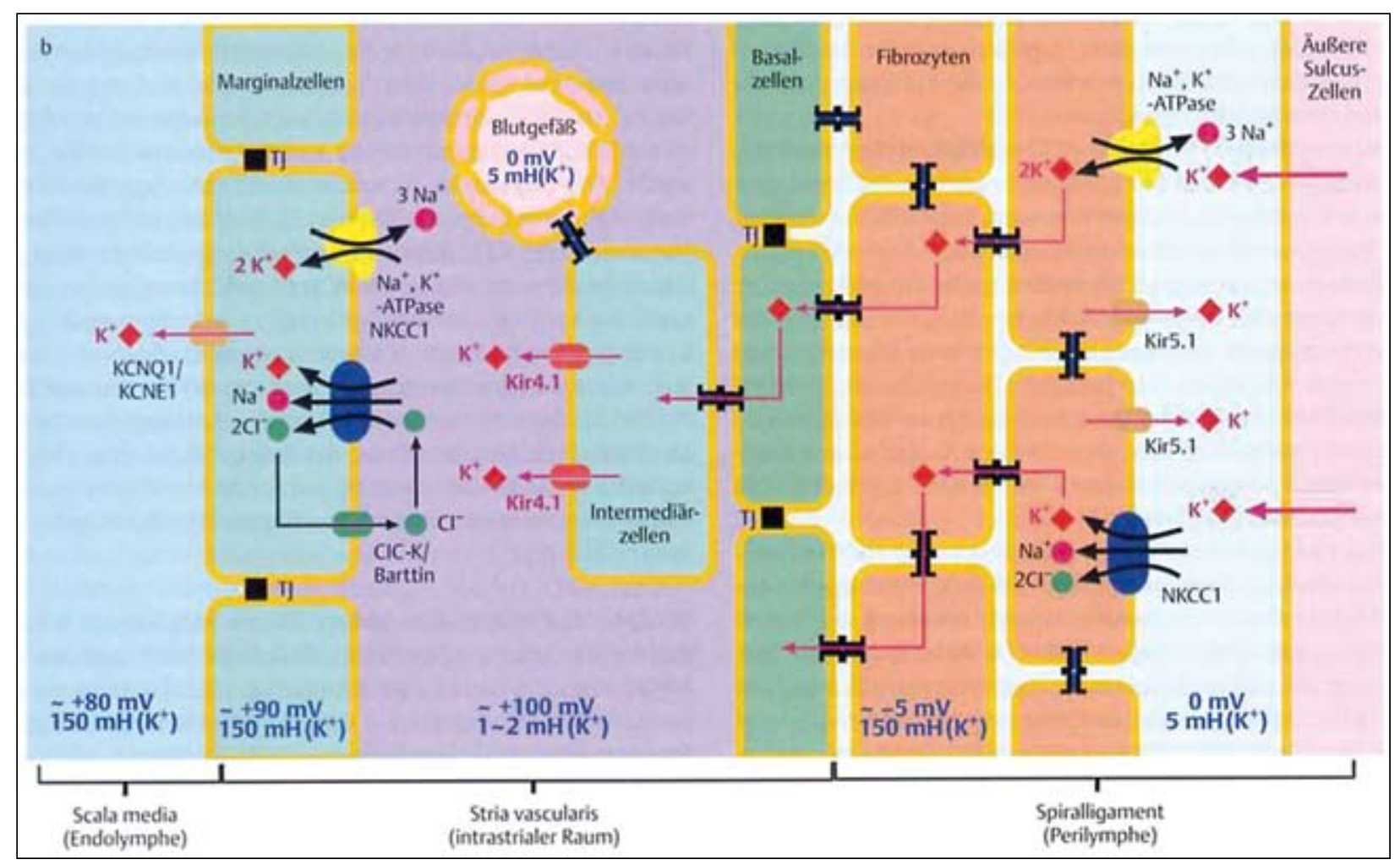

Фиг. 5. Схематично представяне на stria vascularis (виж текста) 
фиг. 5 са скицирани начините на протичане на калиевата циркулация и начина на формиране на ендокохлеарния потенциал (25). Последствията от нарушаване на циркулацията на калиевата осмоза води до тежки нарушения на слуха. Доказано е, че при подобни нарушения са отговорни мутация на ген KCNE1 и KCNQ 1.

$\boldsymbol{K C N Q}$ 1. KCNQ1 е ген кодиран за синтезата на alpha субединици на контрактилните KvLQT1калиевите канали на stria vascularis (виж фиг. 2). Във вътрешното ухо е възможно този тип канали да секретират калии и в stria media.

Една аутозомно доминантна мутация на KCNQ1 локализирана на късото рамо на хромозома 11 (11p15.5) води до появата на Jervell-Lange- Nilsen syndrom.Този синдром клинично се представя от удължен електрокардиографски комплекс QT type 1(LQT1) и вродена силно изразена приемна глухота. Патофизологично е нарушена реполяризация на кардиомиоцитите съпроводено с появата на патологична ререполяризация и наличие на удължена рефрактерна фаза, както и инсуфициенция на калиева секреция от маргиналните клетки на stria vascularis,което намалява калиевата концентрация и води до нарушена трансдукция на слуховите клетки.

KCNQ4. KCNQ4 ген е кодиран за управление синтезата на един компонент ретрактилен протеин за калиевите канали,който е локализиран върху DFNA2, разполагащ се на базолатералната страна на слуховите клетки (28). Мутацията на KCNQ4 води до проявата на прогресираща несиндромална приемна пълна глухота. Тук се касае до типична за по-късната възраст проявена (след втората декада), но със запазена добра разбираемост на говора глухота, която с напредване (около 10 години) от началото на заболяването води до пълна кофоза. Вероятно познатите гени, които са асоцирани с калиевата хомеостаза, са тези които се свързани с синтезата на конексина. Connexine са една фамилия от трансмембранни протеини, които в клетките изпълняват ролята на Gap junction. Възможно е те освен молекули да обменят и протеини с големина от около $1 \mathrm{kDa}$, което все още не е напълно доказано. Конексините са едни от значимите функционални елементи на калиевата обмяна в опорните спомагателни клетки на organon Corti, ligamentum spiralae и stria vascularis (29).

Connexin 26 и 30. Мутацията на гените кодирани за продукцията на Connexin 26 и 30 са причи- на за многобройни несиндромални хередитарни намаления на слуха (29), които са причина за около $85 \%$ от случаите за прелингвална глухота или глухота непосредствено развила се след раждането. Типично за тях е липсата на други патологични лезии на вътрешното ухо. Connexin 26 се експримира в редица Gap Junctions на опорните клетки на кохлеята, на спиралния лигамент и на limbus spiralis cochleae $(30,31)$. Генът GJB2 кодиран за продукцията на Connexin 26 се локализира в мястото на DFNB1. Над половината рецесивна несиндромална глухота и около 30-50\% от вродената глухота се обуславя от мутациия на ген GJB2. За над $70 \%$ от всички GJB 2 мутации се намира един определен вариант на мутация (35 delG), отговорна за аномална конструкция на Connexin 30. Connexin 30 е протеин продукт фабрициран върху матрицата на GJB 6 Gen, които като GJB2 е локализиран на DFNB1(32).

\section{3. Течностна хомеостаза. Кохлеарната хоме-} остаза е от решително значение за състоянието на ендокохлеарните потенциали и механотранстдукцията. Във вътрешното ухо се намират три различни необикновени вида по техния състав течности: ендолимфа, перилимфа и интрастриална течност, scala media се запълва с ендолимфa, scala vestibuli et scala tympani са изпълнени с перилимфа.

Ендолимфата е богата на калии и бедна на натрий, докато перилимфата и интрастриалната течност са много по-богати на натрий и бедна на калий. Регулирането на тези йонни компоненти в течностите във вътрешното ухо са реализира от множество транспорти връзки осъществявани през различните канали (33). Както вече преди съобщихме различната електролитната концентрация в тези течности е отговорна за поддържането на съответните ендокохлеарни потенциали. B stria vascularis наличният Na-K$\mathrm{Cl}$ котранспорт и една $\mathrm{Na}^{+} / \mathrm{K}^{+}-$ATPase са отговорни за йонния транспорт ,които при високата натриева и при ниската калиева концентрация поддържат интрастриалните потенциали. СIC$\mathrm{K} /$ Barrtin каналите са отговорни за това, че $\mathrm{Cl}^{+}$ йонни се транспортират обратно в интрастриалното пространство. Локализацията на и функцията на някои от тази система се намират схематично представена на фиг. 5. Значението на $\mathrm{Na}-$ $\mathrm{K}-\mathrm{Cl}$ котранспората и $\mathrm{Na}^{+} / \mathrm{K}^{+}$-ATPase показват впечатляващо значително намаление на ендо- 
кохлеарните потенциали при експерименталното въвеждана на бримковите диуретици .

Bartter syndrom. Мутацията на Barttin-gen, кодиран само за една $\beta$ единица на CIC-K-канала дава симптомите на Bartter syndrom type 4, типизиращ се с глухота и ренална загуба на сол. Същото се наблюдава и при Со-случаи при която се намира мутация на $\mathrm{Cl}^{+}$канал CLCNKA и CLCNKB. Последствието на тези спонтанни мутации е нарушено формиране на ендокохлеарните потенциали и силно нарушено приемно намаление на слуха до пълна глухота $(34,35)$. Регулацията на ендолимфатичните $\mathrm{Ca}^{2+}$ концентрация е от решително значение за физиологичната функция на organon spirale Corti и то не само за състоянието на трансдукционните потенциали, но също и за адаптацията и кохлеарното усилване. Регулацията на кохлеарните обеми на течностите е също така от голямо значение. Между физиологичните условия се приема, че един лонгитудинален поток на ендолимфата има значение за хомеостазата на течностите. Така например увеличаване обема на ендолимфатичното пространство създава условия за насочване потока на ендолимфата към основата на кохлеята и редукция на ендолимфатичния обем и обратно, при намаляване на ендолимфатичния обем потокът се насочва към арех cochlea. При нормалните физиологични условия изглежда липсват подобни промени в обема на ендокохлеарните течности. За трансмембранозният транспорт на водата във вътрешното ухо изглежда играе важна роля епитела на ендолимфатичните различни пориподобни воднопермеабилни канали с Aquaporine. Приема се към настоящият момент, че aquaporine 4 е от особено значение за транспорта на водата във вътрешното ухо (36).

Morbus Meniere. Високото нива на вазопресин води до hydrops endolymphaticum, морфологичната характеристика на morbus Meniere. Вазопресиновите антагонисти са пък в състояние да предизвикат колапс на ендолимфатичните циписти структури, като причината за подобни промени все още е неизяснена. Предполага се, че vasopressin-ът регулира експресирането на Aquaporin 2 и по този начин повишава водната резорбция (36). Способността на коритикостероидите да подтиснат манифестните симптоми на morbus. Meniere е поради подтискане продукция на вазопресин респ. на вода и намаляване продукцията на aquaporine. По този начин се

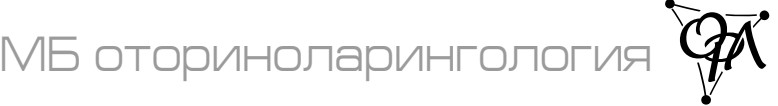

доказва, че хормоналното въздействие върху фабрикацията на вазопресина води до повлияване течностната хомеостаза. Вазопресинът управлява експресията на aquaporin в клетьчните мембрани, но повишава също и активността на епителиалните $\mathrm{Na}^{+}-$и $\mathrm{Na}^{+} / \mathrm{K}^{+} / 2 \mathrm{Cl}^{-}$контранспорта в стриалните маргинални клетки и type II фиброцити на ligamentum spiralae. Като възможно последствие на подобен дисрегулационен баланс е повишаване на $\mathrm{K}^{+}$секреция в ендолимфата и последващо осмотична промяна в състава на течностите и хидропс. Подобен ефект се разгръща и при включване на aldosteron, който активира епителиалните $\mathrm{Na}^{+}$канали и $\mathrm{Na}^{+} / \mathrm{K}^{+}$/ ATP ase (37). Другите хормони, като например глюкокортикостероиди имат противоположен ефект върху вазопресина. По тази причина те намаляват ярката симптоматика на m. Meniere поради намалената продукция на вазопресин и експресията на аквапорин. В заключение може да се твърди уверено, че кохлеарната течностна хомеосмоза, йонната хомеосмоза и ендокохлеарните потенциали са от решаващо значение за кохлеарната функция.

\section{Ganglion spiralae}

1. Въведение. Спиралният ганглии представлява струпване на нервни клетки в сравнително тясното пространство на canalis spiralis modioli (canalis Rosenthal), който е съставени от аферентната инервация на Кортиевия орган. Там се намират телата на клетките с аферентните неврони, дендритите, които се насочват към слуховите ресничести клетки, докато аксоните в състава на n.cochlearis достигат nucleus cochlearis в мозъчния ствол. Аферентните влакна от Тур I - на спиралните ганглийни неврони са миелинизирани и достигат вътрешните слухови клетки. Аферентните влакна на тип II спирални ганглийни клетки са немиелинизирани и водят до външните слухови клетки. Около 90\% от аферентните влакна започват от долната част на клетката, като всяко влакно създава синаптечен контакт само с една вътрешна слухова клетка. Външните слухови клетки се инервират едва около $10 \%$ от аферентните влакна, при което много външни клетки се конвергират от едно влакно (фиг. 6). Тази различна инервация показва и различно функционално значение на вътрешните и външните слухови клетки. Акустичната информация накрая се пренася 


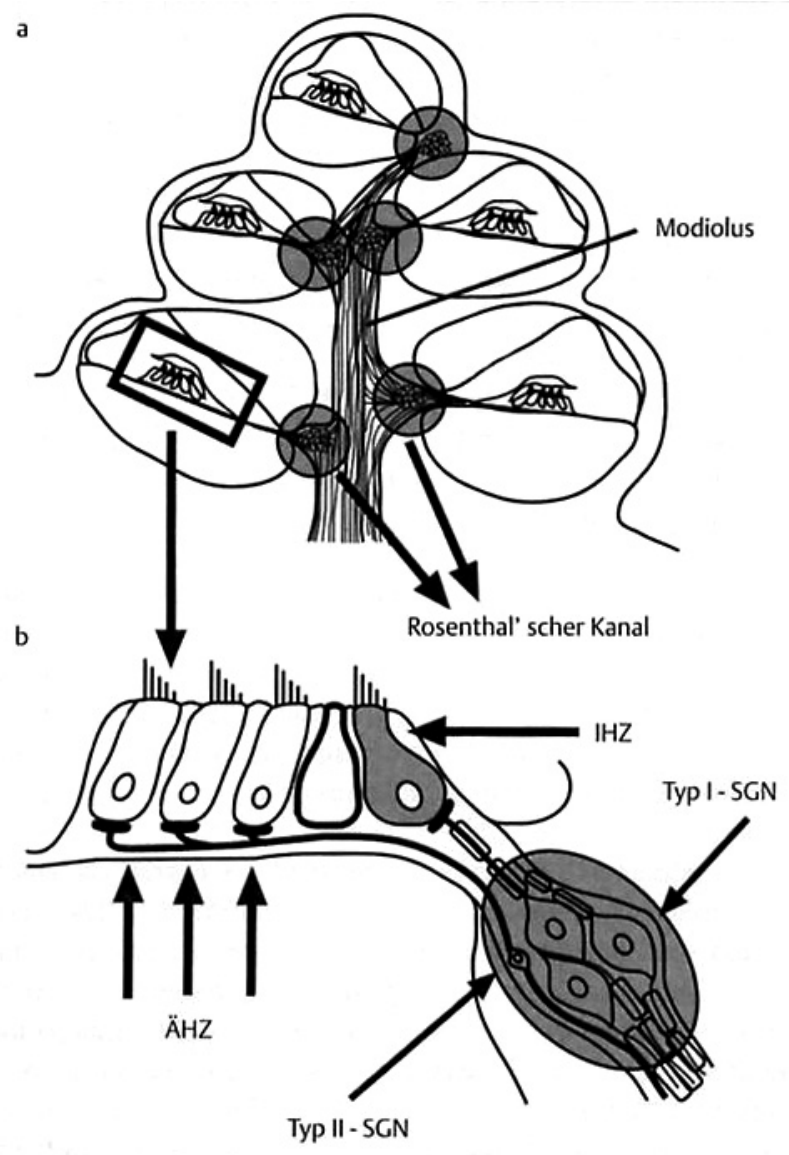

Фиг. 6. Ganglion spiralae-AHZ - външни слухови клетки IHZ вътрешни слухови клетки, Typ I-SGN - тип първи спирален ганглиен неврон, Typ II-SGN - втори спирален ганглиен неврон

посредством аферентната система от влакна към мозъчния ствол.

2. Синапси на слуховите клетки. Всяка една от слуховите клетки изгражда система от синаптични контакти със спиралните ганглийни неврони. Аферентните синапси са високо специализирани, както в тяхната форма така и в тяхната функция. Изградената синаптична връзка („Ribbon-synapse“) се състои от една пресинаптична активна зона и една синаптична връзка. Последната е значително по-малка от 1 $\mu \mathrm{m}$ голяма и обградена от около 100 синаптични везикули. В зоната на постсинаптичнине нервни окончания се намират йонотропни глутамат рецептори от АМРА-Туре. Комплексната структура на системата от контактни връзки създават възможност за високо скоростно честотно пренасяне на сигналите при ниско рефрактерно време. За синтезата на контактната система са от значение калциевите канали от Сav 1,3 Тур които се активират от рецепторните потенциали на ресничестите клетки. При по-нататъшно- то действие в постсинаптичните окончания се активират глутамат рецепторите. По този начин се формират ексцитационните постсинаптични потенциали, които под формата на акционни потенциали се трасбордират по- нагоре в централната нервна система.

2.1. Cav 1,3 калциеви канали, Otoferlin. В модели на мишки е било демонстрирано, как едно нарушение на вътрешните слухови клетки и техните синапси води до намален слух и пълна глухота. При генетичните изключвания на Cav 1,3 калиеви канали са показвали редукция на калциевия поток с около 90 \%, при което акустично евоциираните потенциали на мозъчния ствол не са доказвани и регистрирани. $(38,39)$. Така например една мутация на OTOF gen кодиран за продукция на протеина otoferlin, дава синаптичен дефект който може да доведе до синаптичен дефект при човешка прелингвална глухота тип DFNB9 (40). Слуховите стволови потенциали е възможно да бъдат евокирани в модел на мишки с намален слух тип DFNB9. Както при Cav 1,3„knock-out“", така също и при otoferlin - „knock out“" ce манифестира с приблизително пълно блокиране на синаптичното пренасяне с високо степенно намаление на слуха и е пример за синаптична глухота (41). Наблюдавани са също така и слухови синапсопатии както, например при хипербилирубинемия и тежка хипоксия при преждевременно родени. Възможно е също така и развитие увреждане на вътрешните слухови клетки при платина съдържащите химиотерапевтици (М. Маринов и сьтр.) и звукова травма. Предполага се, че при тези състояния настьпват екстремално увреждане на постсинаптичните спирален ганглион неврони поради екцесивното освобождаване на глутамат.

2.2. Честотно кодиране в слуховия нерв. Тонотопичната организация в кохлеята се продължава и в аферентната система на слуховия нерв. Всяко място на базалната мембрана се стимулира от механичното честотно раздвижване на мембраната. Съответните на инервационните топики стимулираните вътрешни слухови клетки и аферентните им неврони се силно възбуждат, ако акустичния сигнал е с една сигнална компонента,която на това място най-силно възбужда слуховата клетка. Всеки аферентен неврон притежава качествата на фреквентен филтьр под формата на неговата честотно съгласувана крива (Tuning). При всички звукови интензите- 
ти нервните влакна увеличават също възбудата от най-ниските до най-високите фреквенции. Тук тонотопията се основава на два кодиращи допълващи се принципа - фазово свързване (Phase locking). Фазовото свързване се основава на времевите образи на акционния потенциал, който се намира в адекватна връзка с фазата на рецепторния потенциал. Фазовото свързване е от особено значение определяне на пространственото определяне на акустичния източник.

\section{3. Еферентна инервация на кохлеята. Две} групи от различни влакна са отговорни за еферентната инервация на кохлеята. Миелинизираният tractus olivocochleare medialae (ТОС), водят началото си от горната медиална олива, след

\section{Литература:}

1. Starlinger, V., K. Masaki, S . Heller. (2010) „Auditory Physiology, Inner Ear" Glasscock Shambaugh Surgary of the Ear, Peapels Medical Publicationg House, 73-87

2. Raphael, Y. RA. Altschuler (2003) Brein Re Bull. 60, 397-422.

3. Hundspeth, Aj.(1997) „Neuron“ 19, 947-950

4. Vollrath, MA. KY. Knwn, DP. Corry (2007) „Annu Rev neurosci.“ 30, 339-365

5. Gillepsie, PG., RC. Walker (2001) „Nature“ 413, 194-202

6. Hundspeth, AJ. PG. Gillepsie, (1994) „Neuron“ 12, 1-9

7. Hudspeth, AJ. (2005) „C. R. Biol.“ 328, 155-162

8. Gillepsie, PG, U. Müller (2009) „Cell“ 139, 33-44

9. Sakaguchi, H.B. Kachar, H. Takita, J. Muller (2009) „Curr. Opin. Otolaryngol. Head and Neck“" 17, 388-393

10. Müller, U. (2008) Curr.Opin.Cell Biol.“ 20, 557-566

11. Ahmed, ZM. et all.(2006) J. Neurosci.“ 26, 7022-7034

12. Corey, DP. (2006) ,J. Physiol.“ 576, 23-28

13. Gillepsie, PG, RA. Dumont, B. Kachar (2005) „Curr. Opin. neurobiol.“ $15,389-396$

14. Gillepsie, PG. (2004) „Philos Trans R. Soc. Lond. B. Biol. Soc.“ 359, 1945-1951

15. Weil, D. et all. (1995) „Nature“ 374, 60-61

16. Weil, D. (1996) „Proc. Natl. Acad. Sci USA“ 93, 3232-3237

17. Maubartet, C. et all.(2005) „Ophthalmic genetic“ 26, 25-29

18. Dallos, P. (2008) „Curr. Opin. Neurobiol.“ 18, 370-376

19. Holt, JR. et all. (2002) „Cell“ 108, 371-381

20. Hudspeth, AJ. (2008) „Neuron“ 59, 530-545 което се разделят, една част се насочва ипсилатерално, а другата се кръстосва контралатерално, където контактуват с холинергичните синапси с външните слухови клетки. Втората група от нервни влакна са немиелинизирани и пътуват в tractus olivocochleare lateralae (TOL), които се отделят от латералната горна олива, насочват се ипсилатерално и навлизат в кохлеята, където формират синаптични контакти с аферентните неврони от type I на спиралния ганглии. За функцията на еферентната система се приема подобреното усилване на отношението сигналшум и контрола на кохлеарната усилване.
21. Ashmore, J. (2008) „Physiol. Rev.“ 88, 173-210

22. Liu, XZ. et all. (2003) „Hum. Mol. Genet.“ 12, 1155-1162

23. Toth,T. et all. (2007) „Int. J. Mol. Med.“ 20, 545-550

23. Zheng, J.et all. (2000) „Nature“ 405, 149-155.

24. Libermann, MC. et all. (2002) „Natura“ 419, 300-304

25. Wangenmann, P. (2006) „J. Physiol.“ 576, 11-21

26. Salt, AN. (2001) ,Singular Thompson Learning“ 333-335

27. Heller, S. (2002) „J. Physiol.“ 534, 3-12

28. Kharkovets, T. et all. (2000) „Proc. Natl. Acad. Sci. USA“ 97, 4333-4338

29. Birkenhager, R. et all.(2007) „Laryngorhinolootologie“ 86, 299309

30. Kikuchi, T. et all.(1995) „Anat.Embriol.(Berl.)“ 191, 101-118

31. Lautermann, J.et all.(1998) „Cell Tissue Res.“ 294, 415-420

32. Lerer, I. et all. (2001) „Hum. Mutat.“ 18, 460

33. Lang, F. et all. (2007) Am. J. Phygiol. Cell. Physiol.“ 293, C 1187C 1208

34. Ando, M., S. Takeuchi (2000) „Neurosci lett.“ 284, 171-174

35. Qu, C. et all. (2006) „hear Res.“ 213, 79-86

36. Hirt, B., et all. (2010) „Neurosciens“ 168, 957-970

37. Mhatre, AN. et all. (2002) „Hear Res.“ 170, 59-69

38. Brandt, A., J. Strissnig, T. Moser (2003) „J. Neurosci“ 23, 1083210840

39. Dou, H. et all. (2004) „J. Assoc. Res. Otolaryngol.“ 5, 215-226

40. Schug, N. et all. (2006) „Eur. J. Neurosci.“ 24, 3374-3380

41. Strenzke, N. et all. (2008) „HNO“ 56, 27-36 